\title{
Changes in the trophic level of an Alpine lake, Jezero v Ledvici (NW Slovenia), induced by earthquakes and climate change
}

\author{
Anton BRANCELJ*, Milijan ŠIŠKO, Andrea LAMI ${ }^{1)}$, Peter APPLEBY ${ }^{2)}$, David M. LIVINGSTONE ${ }^{3)}$, \\ Irena REJEC-BRANCELJ ${ }^{4)}$ and Darko OGRIN ${ }^{5)}$ \\ National Institute of Biology, Večna pot 111, 1000 Ljubljana, Slovenia \\ ${ }^{1)} \mathrm{CNR}$ - Istituto Italiano di Idrobiologia, Largo Tonolli 50, Pallanza I-28922, Italy \\ ${ }^{2)}$ Dept. of Math. Sci., University of Liverpool, Liverpool L69 3BX, UK \\ ${ }^{3}$ Water Resources Dept., EAWAG, Überlandstrasse 133, CH-8600 Dübendorf, Switzerland \\ ${ }^{4)}$ National Institute of Geography, Trg Francoske revolucije 7, 1000 Ljubljana, Slovenia \\ ${ }^{5)}$ Dept. of Geography, Faculty of Philosophy, Aškerčeva 12, 1000 Ljubljana, Slovenia \\ *e-mail corresponding author: anton.brancelj@uni-lj.si
}

\begin{abstract}
Despite relatively high nutrient levels, the Slovenian Alpine lake Jezero v Ledvici (1824 m a.s.l.; max. depth $15 \mathrm{~m})$ is oligotrophic, with high transparency and low chlorophyll concentrations $\left(<1 \mu \mathrm{g} l^{-1}\right)$. Daily mean air temperatures at the lake are estimated to vary between $-15.4{ }^{\circ} \mathrm{C}$ and $+18.8^{\circ} \mathrm{C}$. Low air temperatures combined with the blocking of incident solar radiation by the local topography result in the lake being ice-covered for over six months of the year, suggesting that the effects of climate on the ecology of the lake may be mediated by the timing of the ice cover. Sediment cores taken in 1996 were dated by ${ }^{210} \mathrm{~Pb}$ and ${ }^{137} \mathrm{Cs}$ and analysed for $D W, L O I$, cladoceran and diatom remains, pigments, $C, N$ and $S$. A total of 50 diatom taxa and 4 cladoceran taxa were found. The base of the unsupported ${ }^{210} \mathrm{~Pb}$ record at $17.4 \mathrm{~cm}$ was dated to $1825 \mathrm{AD} \pm 25 \mathrm{y}$. An abrupt change in DW and LOI was observed at a depth of $17 \mathrm{~cm}$, coinciding with a change in the cladoceran community and in $C$ and $N$ concentrations. From a depth of $12 \mathrm{~cm}(83 \pm 4$ y BP) upward, a sharp change in $S$ and plant pigment concentrations were recorded, followed by an increase in diatom abundance at a depth of about $10 \mathrm{~cm}(63 \pm 4$ y BP). The timing of quantitative changes in the physical and chemical properties of the sediment, and in the community structure of diatoms and Cladocera, coincides with the occurrence of three earthquakes in the $19^{\text {th }}$ century. Changes in the diatom and cladoceran record were compared with a tree-ring width index based on Larix decidua from the shore of the lake over the last 136 years, and with reconstructed air temperatures from 1781 - 1996. With a 4-y lag, a weak positive correlation exists between the tree-ring width index and the air temperatures. Although diatom abundance generally shows no correlation with the tree-ring width index, a negative correlation was found in the case of Fragilaria pinnata and Amphora lybica, interrupted only between 1942 and 1955. A similar pattern to this latter was also observed in the case of the Cladocera. During the last $250 y$, anthropogenic influence on the lake catchment area has been confined mainly to limited sheep grazing. The main cause of changes occurring in the lake itself is likely to be eutrophication resulting from the input of allochthonous material from landslides triggered by earthquakes. During the last three decades, however, the main factor influencing biotic change appears to have been the increase in mean air temperature, possibly acting via ice cover.
\end{abstract}

Key words: Cladocera, climate change, diatoms, earthquake, eutrophication, meteorology, palaeolimnology, pigments, sediment

\section{INTRODUCTION}

Recognition of the effects of environmental change induced by human activity has resulted in an increased interest in reconstructing the state of the environment in the past (Battarbee 1995). In central and southern Europe it is now relatively difficult to find lakes which are not directly affected by human activity. The only possible exceptions to this are high-mountain lakes, but even these are influenced by airborne pollution (Mosello et al. 1995a; Psenner 1995). As a result there is increased acidification of these lakes, particularly those with soft water (Camarero et al. 1995) or enhanced nutrient input (Mosello et al. 1995b). As the lake sediment represents a time capsule for events occurring within the lake and its surroundings, sediments from remote lakes are among the most suitable for reconstructing envi- ronmental changes (Oviatt et al. 1994). In deep, stratified lakes, sediments are deposited in chronological order, and the analysis of plant and animal remains can reveal the historical development of the lakes (Hofmann 1987). Sediment cores can cover a time span of several years to several thousand years. Dating on short time scales (up to 150 y) can be conducted successfully using the ${ }^{210} \mathrm{~Pb}$ method (Oldfield \& Appleby 1984; Joshi et al. 1988; Appleby 1993).

The value of lacustrine biological remains as indicators of past environment and climate has been emphasised in many publications (e.g. Smol 1990; Bradbury \& Dean 1993). Among the biological records, the siliceous valves of diatoms and chrysophyte cysts are generally abundant and well preserved in lake sediments. Diatoms are sensitive ecological indicators and have been widely used to reconstruct changes in $\mathrm{pH}$ (Battarbee 1995), salinity (Fritz 1989) and nutrients (e.g. Bennion 1994). 
Cladoceran remains have also been extensively used for palaeoenvironmental reconstruction (Berglund 1986; Manca et al. 1994). Plant pigments can serve as indices of present and past trophic conditions, and are useful for revealing successive changes in glacial and post-glacial ecology, limnology and climate, especially changes in postglacial aquatic productivity (Swain 1985; Sanger 1988). In conjunction with other proxy records, pigments can provide further information on the balance between allochthonous and autochthonous organic contributions to the sediment, redox conditions, and past periods of meromixis (Lami et al. 1994).

Some environmental factors which affect terrestrial systems, resulting in increased or decreased bioproduction (e.g., temperature, insolation, precipitation: Mosello et al. 1995b), might have similar effects on lake ecosystems. A useful tool for the reconstruction of palaeoenvironments in terrestrial ecosystems is tree-ring analysis. Variations in the width of tree-rings through time are a useful indicator of environmental change (Rolland 1993) and can be compared with sediment rec??ords.

In some regions, earthquakes may play an important role in causing environmental change for lacustrine ecosystems. They can cause changes in lake bathymetry and/or increases in trophic level as a result of landslides, inwash of allochthonous material or tectonic movements (Jacoby et al. 1992; Karlin \& Abella 1992; Mirecki 1996).

This paper will focus on the results of a palaeolimnological study of Jezero $\mathrm{v}$ Ledvici, the most oligotrophic mountain lake in Slovenia. The lake is located at an altitude of about $1824 \mathrm{~m}$ a.s.l. on an alpine plateau in the centre of the Julian Alps. The Julian Alps are in a seismically very active part of Slovenia, and there are records of a number of relatively strong earthquakes (EMS >3.5) having occurred there, most recently in 1976 and 1997 (Ribarič 1982; Ribičič \& Vidrih 1999). The 1997 earthquake triggered a number of landslides, some with a volume of several tens of thousands of cubic metres (Ribičič \& Vidrih 1999). Within the last $100 \mathrm{y}$, two other strong earthquakes were also recorded - in 1895 and 1942 (Ribarič 1982, Vidrih et al. 1995).

In the past, there was very little human activity in the vicinity of the lake apart from seasonal pasturing, which ended there before the First World War, and logging, which stopped in the 19th century (Melik 1950).

The main aim of the present study was to attempt to reconstruct the history of this lake and its catchment area using a palaeolimnological approach, focusing especially on the last $150 \mathrm{y}$, during which industrialisation and the resulting pollution can be assumed to have had their greatest impact. Subsequently, during our study of the sediment, we found that the lake had also been affected significantly by earthquakes and landslides on at least three occasions.

\section{SITE DESCRIPTION}

Jezero v Ledvici is an Alpine lake located at $1824 \mathrm{~m}$ a.s.l in NW Slovenia $\left(46^{\circ} 20^{\prime} 30^{\prime \prime} \mathrm{N}, 13^{\circ} 47^{\prime} 20^{\prime \prime} \mathrm{E}\right)$. It is 15 $\mathrm{m}$ deep, $300 \mathrm{~m}$ long and 75 to $130 \mathrm{~m}$ wide, with a surface area of 2.37 ha (Fig. 1). The valley and lake basin are glacial relicts. The surroundings consist of Jurassic carbonates, with frequent surface and subterranean karst phenomena. The surrounding slopes are mainly bare rock, with some dwarf pine (Pinus mughi) or small patches of grass. The trees in the area are predominantly European larch (Larix decidua), and the lake is located just above the treeline.

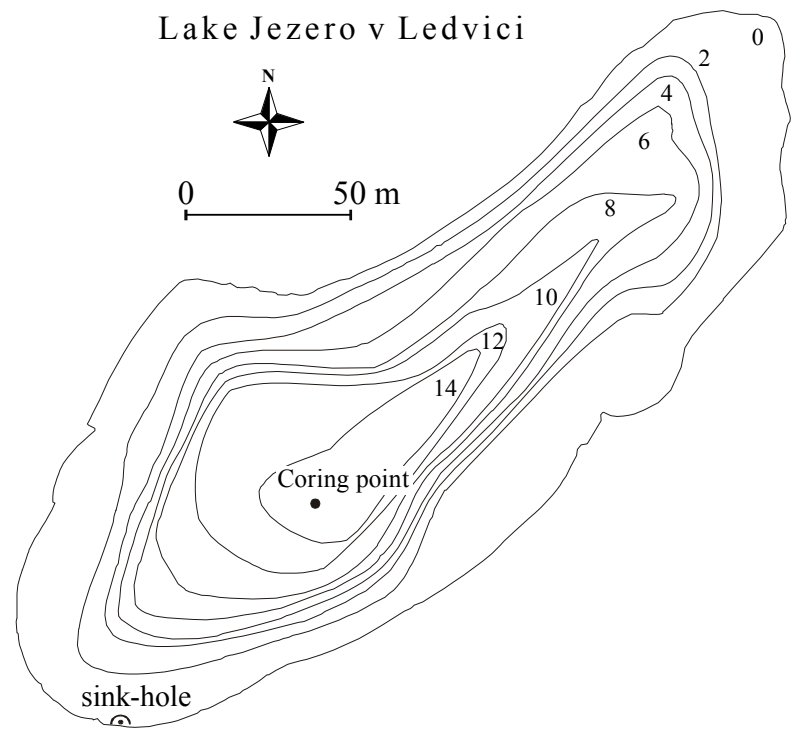

Fig. 1. Bathymetric map of the mountain lake Jezero v Ledvici (NW Slovenia) showing core sampling site (black dot) and sink-hole outlet.

The lake has no permanent surface inflow. After heavy rains or during snowmelt, only a small temporary surface inflow exists, and some small temporary underwater springs also occur. The outflow is a sink-hole in the southernmost part of the lake, partly filled with boulders and gravel. The eastern bank of the lake is very steep, with an inclination of $45^{\circ}-50^{\circ}$, and consists of a slope of small rocks and sand accumulated beneath a cliff about $300 \mathrm{~m}$ high. This slope extends right into the lake itself, so that some re-suspension of littoral sediment would be likely to occur here during a landslide.

The lake is oligotrophic: light penetrates down to the lake bottom, and chlorophyll concentrations are below 1 $\mu \mathrm{g} \mathrm{1^{-1 }}$. On average, concentrations of total phosphorus $\left(25 \mu \mathrm{g} \mathrm{l}^{-1}\right)$ and total nitrogen $\left(1024 \mu \mathrm{g}^{-1}\right)$ are relatively high, as are concentrations of $\mathrm{P}_{-} \mathrm{PO}_{4}\left(2 \mu \mathrm{g} \mathrm{l}^{-1}\right)$ and N$\mathrm{NO}_{3}\left(337 \mu \mathrm{g}^{-1}\right)$. The lake water has a high alkalinity $\left(>1500 \mu \mathrm{eq} 1^{-1}\right)$ and is slightly basic $(\mathrm{pH} 7.3-8.1)$ because of the underlying limestone. Oxygen saturation levels in the water column almost always lie between 100 and $110 \%$, apart from a short period before the ice melt, when they can drop to $50 \%$ (Brancelj, unpubl.). 
However, especially during period of longer icecover, the sediment-water interface becomes anoxic since sedimentary carotenoids belonging to sulphur photosynthetic bacteria have been found (Lami et al. 2000 , this issue).

In the lake there are 50 diatom species, all of them benthic. The most common are Achnanthes minutissima, Denticula tenuis and Navicula cryptotenella. There are two species of copepods in the plankton (Arctodiaptomus alpinus and Cyclops abyssorum tatricus) and one cladoceran species (Daphnia longispina). The zooplankton biomass varies between $0.01 \mathrm{~g} \mathrm{DW} \mathrm{m}^{-3}$ (in spring) to $0.2 \mathrm{~g} \mathrm{DW} \mathrm{m}^{-3}$ (in autumn). The lake has no fish (Brancelj et al. 1997).

In the littoral zone, ephemeropteran larvae (Siphlonurus lacustris), colleopteran adults (Agabus bipustulatus and A. undulatus) and several chironomid species occur. A systematic survey of the biota of the lake revealed only four cladoceran species, three of which were benthic. Two of these benthic species are common (Biapertura affinis = Alona affinis and Chydorus sphaericus), while the third, Alona rectangula, is rare (Brancelj et al. 1997).

\section{MATERIAL AND METHODS}

\subsection{Meteorological data}

A Delta-T automatic weather station (AWS) was employed from 1 October 1996 to 30 September 1998 to obtain information that would allow the prevailing meteorological conditions at the lake to be characterised. For reasons of security, the AWS was deployed on the roof of an abandoned cottage $2.5 \mathrm{~km}$ south of the lake; the measured data therefore, while representative of the local vicinity of the lake, may not be completely representative of the lake itself. The sensors were located at $1720 \mathrm{~m}$ a.s.l. (104 $\mathrm{m}$ below the lake surface). Air temperature, solar and net radiation, air pressure, relative humidity, precipitation, wind speed and wind direction were measured every $30 \mathrm{~min}$. In addition, the presence or absence of ice on the lake was noted each time the site was visited.

\subsection{Sediment sampling}

Five cores were taken at the deepest part of the lake in August 1996 using a gravity corer. On the lakeshore, four cores (labelled LEDV2 to LEDV5) were immediately cut into $2 \mathrm{~mm}$ thin slices. From each slice, subsamples for different analyses (physical sediment properties, dating, pigments, SCP, organic pollutants, cladoceran, chironomid and diatom remains) were collected. Core LEDV4 was used for the analysis of pigments, C, $\mathrm{N}$ and $\mathrm{S}$ concentrations, DW, LOI, and cladoceran and diatom remains. Core LEDV5 was used for ${ }^{210} \mathrm{~Pb}$ dating. An additional sixth core (LEDV6) was taken for the visual analysis of the vertical cross-section of the sediment to record changes in colour and structure. For de- tails of the methods, analyses and core-to-core correlation, including those for cores LEDV2 and 3, see Brancelj et al. (in prep.).

\subsection{Sediment dating}

Core LEDV5 was analysed for ${ }^{210} \mathrm{~Pb},{ }^{226} \mathrm{Ra},{ }^{137} \mathrm{Cs}$ and ${ }^{241} \mathrm{Am}$ by direct gamma assay, using an Ortec HPGe GWL series, well-type, coaxial low background intrinsic germanium detector (Appleby et al. 1986). 210Pb was determined via its gamma emissions at $46.5 \mathrm{keV}$, and ${ }^{226} \mathrm{Ra}$ by the $295 \mathrm{keV}$ and $352 \mathrm{keV} \gamma$-rays emitted by its daughter isotope ${ }^{210} \mathrm{~Pb}$ following 3 weeks storage in sealed containers to allow radioactive equilibration. ${ }^{137} \mathrm{Cs}$ and ${ }^{241} \mathrm{Am}$ were measured by their emissions at $662 \mathrm{keV}$ and $59.5 \mathrm{keV}$. Corrections were made for the effect of self-absorption of low energy $\gamma$-rays within the sample (Appleby et al. 1992). Dates and sedimentation rates were determined from depth profiles of the activities of ${ }^{210} \mathrm{~Pb},{ }^{137} \mathrm{Cs}$ and ${ }^{241} \mathrm{Am}$ using the procedures described by Appleby $(1993,1998)$.

Loss-on-ignition (LOI), carbon (C), nitrogen (N) and sulphur (S).

Core LEDV4 was selected for organic matter and $\mathrm{CaCO}_{3}$ (not shown) which were determined by loss on ignition at $550{ }^{\circ} \mathrm{C}$ and $950{ }^{\circ} \mathrm{C}$, respectively. Calcium carbonates were calculated according to Dean (1974). These parameters were also measured in all the cores studied in order to give a basis for cores cross-correlation to cores LEDV3, LEDV4 and LEDV5. Total C, N and $\mathrm{S}$ were measured on dried subsamples of about 1015 mg using a Carlo Erba elemental analyser.

\subsection{Pigments}

Core LEDV4 was analysed for total pigments (chlorophylls and their derivatives - CD, and carotenoids TC). Sediment sub-samples were extracted overnight with $5 \mathrm{ml}$ of acetone and water (90:10), then centrifuged at $3000 \mathrm{rpm}$ for $5 \mathrm{~min}$. The surnatant was then removed and adjusted to a final volume of $10 \mathrm{ml}$ and used for spectrophotometric and chromatographic analysis of photosynthetic pigment following the methods described in Lami et al. (2000, this volume). For comparison with previous studies, chlorophyll derivatives were calculated in terms of absorbance units per gram organic matter, one unit being equivalent to an absorbance of 1.0 in a $1 \mathrm{~cm}$ cell when that unit is dissolved in $100 \mathrm{ml}$ of solvent (Wetzel 1970; Lami et al. 1994). Total carotenoids were expressed as mg per gram organic matter (Züllig 1982).

\subsection{Diatom remains}

Core LEDV4 was analysed for diatom remains which were prepared according to standard methods (Battarbee 1986). At least 500 diatom valves per slide were counted under an optical microscope. Diatom concentrations were estimated by adding a known concen- 
tration of latex spheres to the sample before counting. Diatom nomenclature follows that of Krammer \& Lange-Bertalot (1991).

\subsection{Cladoceran remains}

Core LEDV4 was analysed for cladoceran remains, we used the same sample as that employed for the pigment and CNS analyses. The dried samples were put into distilled water and shaken well twice within one hour. Then the samples were sieved through a $40 \mu \mathrm{m}$ nylon mesh and stored in plastic tubes prior to counting. We analysed cladoceran remains using a stereomicroscope at $100 \times$ magnification. Head-shields, post-abdomens and ephippia were counted as one unit, and left and right sides of valves together as one unit. Remains were recalculated as the number of remains per gram of dry weight of sediment. The cladoceran nomenclature follows that of Margaritora (1985).

\subsection{Tree-ring width index and dendroclimatology}

Samples from 12 trees (Larix decidua) from the shore of the lake were collected at chest height, and tree-ring width was measured under a stereomicroscope. For further analyses we followed the instructions of Fritts (1976), Hughes et al. (1982) and Cook \& Kairiukstis (1990). By means of cross-dating we reconstructed an average local tree-ring width index. To test the reaction of the tree to climatic conditions, we used correlation and response functions of the tree-ring width index to meteorological conditions during the last $30 \mathrm{y}$. Relevant meteorological data were obtained from the meteorological station on the Komna Plateau, $6 \mathrm{~km}$ south of the lake, at an elevation of $1520 \mathrm{~m}$.

\section{RESULTS}

\subsection{Local weather conditions at the lake}

A summary of the meteorological data obtained from the AWS is presented in figure 2, allowing the moderately harsh external environmental conditions to which the lake is exposed to be described and characterized. During the period of observation, daily mean air temperatures at the AWS (Fig. 2a) varied between $15.0^{\circ} \mathrm{C}$ and $+19.3^{\circ} \mathrm{C}$. Assuming surface air temperature lapse rates of $3.7^{\circ} \mathrm{C} \mathrm{km}^{-1}$ in winter and $5.4{ }^{\circ} \mathrm{C} \mathrm{km}^{-1}$ in summer, similar to those found in Switzerland (Livingstone \& Lotter 1998), the range of air temperatures occurring at the lake itself can be estimated as $-15.4{ }^{\circ} \mathrm{C}$ to $+18.8{ }^{\circ} \mathrm{C}$. However, extreme negative air temperatures appear to be the exception rather than the rule. Although monthly mean air temperatures at the AWS (Tab. 1) lie slightly below $0{ }^{\circ} \mathrm{C}$ during about 3-4 months of the year, daily mean air temperatures only rarely remain below 0 ${ }^{\circ} \mathrm{C}$ for longer than a few consecutive days. During summer, the daily mean air temperature never falls below $0{ }^{\circ} \mathrm{C}$. The maximum measured daily mean air temperature of $19.3^{\circ} \mathrm{C}$ at the AWS, which occurred during the unusually warm summer of 1998, may not be representative of the area during the recent past; the maximum value of $15.5^{\circ} \mathrm{C}$ measured in 1997 may be more representative. Based on the measured data, the annual mean air temperature at the AWS can be estimated to be $4.0{ }^{\circ} \mathrm{C}$. Using the lapse rates of Livingstone \&Lotter (1998), the annual mean air temperature at the lake itself can be estimated to be $3.6{ }^{\circ} \mathrm{C}$. Again, this may be somewhat high due to the influence of the unusually warm summer of 1998 .

Tab. 1. Monthly mean air temperatures (in ${ }^{\circ} \mathrm{C}$ ) measured at the Jezero $\mathrm{v}$ Ledvici (NW Slovenia) automatic weather station (AWS) from October 1996 to September 1998. Because the AWS was located $104 \mathrm{~m}$ below the lake surface, air temperatures at the lake itself can be estimated to be about $0.4^{\circ} \mathrm{C}$ (winter) to $0.6^{\circ} \mathrm{C}$ (summer) lower than the tabulated values.

\begin{tabular}{lccc}
\hline & 1996 & 1997 & 1998 \\
\hline January & - & -0.6 & -2.2 \\
February & - & -0.8 & 1.3 \\
March & - & 1.0 & -2.5 \\
April & - & -0.2 & 1.3 \\
May & - & 6.6 & - \\
June & - & 9.2 & 10.3 \\
July & - & 10.9 & 12.7 \\
August & - & 11.6 & 13.0 \\
September & - & 9.7 & 7.4 \\
October & 3.6 & 3.7 & - \\
November & 0.5 & 0.4 & - \\
December & -1.7 & -2.5 & - \\
\hline
\end{tabular}

The daily mean incident solar radiation measured at the AWS (Fig. 2b) varies from less than $5 \mathrm{~W} \mathrm{~m}^{-2}$ on some winter days to over $360 \mathrm{~W} \mathrm{~m}^{-2}$ on cloudless summer days. The daily mean clear-sky solar radiation at the latitude and altitude of Jezero v Ledvici was calculated for each day of the year based on the approach described by Brock (1981) with the atmospheric transmission coefficients of Hottel (1976), both neglecting and including the influence of local topography at the AWS and at the lake. The similarity of the two curves B and C in figure $2 \mathrm{~b}$ implies that the influence of local topographic effects on the clear-sky radiation at the AWS is small, never exceeding $16 \mathrm{~W} \mathrm{~m}^{-2}$. The percentage reduction in incident clear-sky solar radiation at the AWS due to local topographic effects exhibits very little seasonal variability, varying between $4 \%$ and $5 \%$, with an annual mean of $4.6 \%$. The seasonal variation in the measured solar radiation agrees quite well with that predicted for clear skies, although the solar radiation measured on cloudless days somewhat exceeds the calculated clear-sky values over most of the year. The effect on the incident solar radiation of reflection, absorption and scattering by cloud cover is strongest in early summer, when the measured solar radiation can vary from between $25 \%$ and $75 \%$ of the theoretical clear-sky radiation over periods of several weeks (in June 1997, for instance, the mean measured radiation was $49.5 \%$ of the mean clear-sky value). Especially during late winter and 


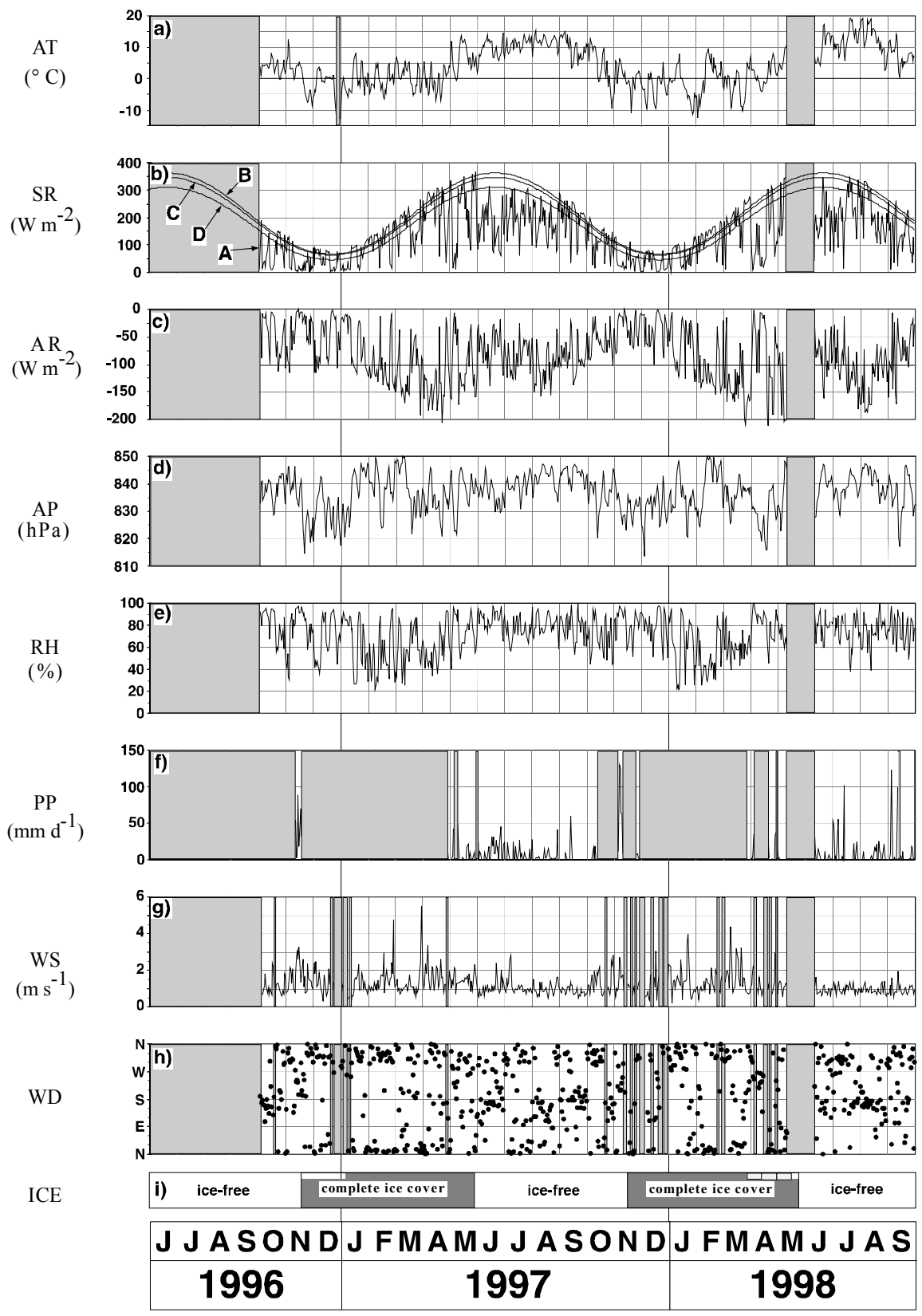

Fig. 2. Meteorological measurements made at the Jezero v Ledvici (NW Slovenia) automatic weather station ( $2.5 \mathrm{~km}$ from the lake and $104 \mathrm{~m}$ lower than the lake surface) and observations of the ice cover of the lake from October 1996 - September 1998 . The measured variables were: a) air temperature (AT); b) short-wave solar radiation (SR); c) net long-wave atmospheric radiation (AR); d) air pressure (AP); e) relative humidity (RH), f) precipitation (PP); g) wind speed (WS); h) vector-averaged wind direction (WD); and i) ice cover (ICE). In b), in addition to the measured data (A), the theoretical clear sky solar radiation calculated according to Brock (1981) using the atmospheric transmission coefficients of Hottel (1976) is shown, unmodified (B) and modified by the local skyline at the AWS (C) and the lake (D). The grey panels indicate periods of no measurement.

spring, the high albedo of a snow-covered landscape can result in the measured solar radiation exceeding the theoretical clear-sky radiation, since some of the radiation reflected upwards from the snowpack will be scattered or re-reflected downwards in the atmosphere, enhancing the measured solar radiation. The curve D (Fig. $2 b)$ illustrates the theoretical clear-sky solar radiation incident on the lake itself. It is clear that the reduction in incident solar radiation due to local topography is sub- stantially greater and more seasonally variable at the lake than at the AWS, varying from a minimum of $20 \mathrm{~W}$ $\mathrm{m}^{-2}$ in December to a maximum of $52 \mathrm{~W} \mathrm{~m}^{-2}$ in July. The percentage reduction varies from $14 \%$ in May to $30 \%$ in January, with an annual mean of $19 \%$. The best estimate of the actual solar radiation incident on the lake is therefore given by clipping the curve measured at the AWS at curve D (or at values slightly above curve D, to account for the above-mentioned albedo effect). 
The daily mean net atmospheric (long-wave) radiation (Fig. 2c) is almost always negative, ranging from $211 \mathrm{~W} \mathrm{~m}^{-2}$ to $+2 \mathrm{~W} \mathrm{~m}^{-2}$. Seasonal variability about the annual mean of $-83 \mathrm{~W} \mathrm{~m}^{-2}$ is strong, with a high net loss of long-wave radiation in spring and a much lower loss in autumn. Monthly mean values range from $-139 \mathrm{~W}$ $\mathrm{m}^{-2}$ (May 1998) to $-32 \mathrm{~W} \mathrm{~m}^{-2}$ (October 1998). Because the net long-wave atmospheric radiation is comparable in magnitude to the incident short-wave radiation during the open-water period, it is likely to play an important role in determining the heat budget of the lake.

The air pressure at the Jezero v Ledvici AWS (Fig. 2d) varies from a mean of $835.3 \mathrm{hPa}$ in spring to 839.6 $\mathrm{hPa}$ in summer (mean air pressure in winter is slightly higher than in spring). Taking account of the $104 \mathrm{~m}$ altitude difference between the AWS and the lake, this corresponds to a range of $824.6 \mathrm{hPa}$ to $829.2 \mathrm{hPa}$ at the lake itself. The annual mean air pressure at the lake $( \pm$ one standard deviation) is estimated to be $826.0 \pm 3.9$ $\mathrm{hPa}$. Applying the empirical formula of Bührer \& Ambühl (1975), this implies a saturation $\mathrm{O}_{2}$ concentration at $4{ }^{\circ} \mathrm{C}$ of $10.7 \pm 0.05 \mathrm{~g} \mathrm{O}_{2} \mathrm{~m}^{-3}$.

Relative humidity at the AWS (Fig. 2e) is fairly constant in summer, but is much lower and more variable in winter. Based on all available data, mean seasonal relative humidities are $66 \%$ in spring, $78 \%$ in summer, $77 \%$ in autumn and $62 \%$ in winter, with an annual mean of $71 \%$. Because of evaporation from the lake surface, the relative humidity at the lake itself may be higher than that measured at the AWS, especially at times of low wind speed.

Precipitation (rain and snow) on the plateau on which the lake is situated is high, averaging 2500-3000 $\mathrm{mm} \mathrm{y}^{-1}$ (Bernot 1998). Detailed information on precipitation from the AWS (Fig. 2f) is limited, since the precipitation gauge only functioned at air temperatures above $0{ }^{\circ} \mathrm{C}$. However, it can be seen that from May to October, some rain can be expected about every second day ( $53 \%$ of the 396 days for which data are available).

Winds (Fig. 2g) are usually not exceptionally strong, although daily mean wind speeds do exceed $3 \mathrm{~m} \mathrm{~s}^{-1}$ at times. Based on all data, the annual mean wind speed can be estimated to be $1.2 \mathrm{~m} \mathrm{~s}^{-1}$. Prevailing wind directions (Fig. 2h), assessed in terms of vector-averaged daily means, are north (39\%), south $(26 \%)$ and west (24\%). Winds from the east (11\%) are less common.

\subsection{Core description (core LEDV6)}

The uppermost $12 \mathrm{~cm}$ of sediment was darkbrown/black in colour, very soft and with coarse particles of organic debris (Fig. 3, right-hand side). Below this there is a $5 \mathrm{~cm}$ thick light-brown layer, which appears homogenous in consistency. In the interval between 17 and $27 \mathrm{~cm}$ the sediment is laminated (eleven intervals), with about $1 \mathrm{~cm}$ thick light and dark-grey layers. In the interval between 27 and $30 \mathrm{~cm}$ the colour of sediment turns to brown.

\subsection{Dating (core LEDV5)}

Equilibrium between total ${ }^{210} \mathrm{~Pb}$ activity and supporting ${ }^{226} \mathrm{Ra}$ occurred at a depth of about $20 \mathrm{~cm}$. Unsupported ${ }^{210} \mathrm{~Pb}$ activity declines irregularly with depth. The profile has several non-monotonic features, the most severe of which occurs between 1.8 and $3.6 \mathrm{~cm}$.

The ${ }^{137}$ Cs activity versus depth profile is dominated by a well-resolved peak at $0.9 \mathrm{~cm}$, recording fallout from the 1986 Chernobyl accident. A smaller ${ }^{137} \mathrm{Cs}$ peak was detected further down the core at $3.9 \mathrm{~cm}$ depth. Its coincidence with a peak in ${ }^{241} \mathrm{Am}$ activity confirms that sediments at this depth record the 1963 weapons fallout maximum.

Figure 4 compares ${ }^{210} \mathrm{~Pb}$ dates calculated using the CRS model and stratigraphic dates determined from the ${ }^{137} \mathrm{Cs}$ and ${ }^{241} \mathrm{Am}$ records. Calculations of the cumulative ${ }^{210} \mathrm{~Pb}$ inventory of the core show that the discrepancies between the two methods result from a significant decline in the net ${ }^{210} \mathrm{~Pb}$ supply to the sediments during the past few decades. Using the methods described by Appleby (1998), four distinct supply regimes were identified: $0-1.3 \mathrm{~cm}$ (dated 1983-96); 1.3-4.9 cm (1956-83); 4.9-8.8 cm (1944-56); and $>8.9 \mathrm{~cm}$ (pre-1944). Applying the CRS model piecewise to each section, using the relevant fluxes (Appleby 1998), the base of the ${ }^{210} \mathrm{~Pb}$ record at $17.4 \mathrm{~cm}$ was dated at $1825 \pm 25 \mathrm{y}$. The results of these calculations (also shown in Fig.4) indicate that sedimentation rates have been relatively uniform since then, apart from three brief episodes of rapid sedimentation. These occurred in the late $19^{\text {th }}$ century, between 1944 and 1956, and in the mid-1970s, and are most likely linked to the earthquakes recorded in this region in 1895, 1942 and 1975/76 (Vidrih 1995).

\subsection{Dry weight (DW), loss on ignition (LOI), carbon $(C)$, nitrogen $(N)$ and sulphur $(S)$}

The dry weight (DW) profile (Fig. 3) is quite uniform at about $7 \%$ w.w. from the top of the core down to $17 \mathrm{~cm}$. However, there are three small peaks of about $13 \%$ w.w. regularly spaced at 4,9 and $14 \mathrm{~cm}$. At $17 \mathrm{~cm}$ there is a clear steep increase in DW to about $16 \%$ w.w. From $16 \mathrm{~cm}$ to the bottom of the core, the DW is again rather stable with a mean value of about $15 \%$ w.w. This part of the core however, contains more spikes than the top part of the sequence, with values as high as $22 \%$ w.w. occurring in places.

The profiles of loss-on-ignition, carbon and nitrogen (Figs 3, 5) generally have an inverse pattern to that of DW. In general, they decrease from the surface down the core, but with a clear, step-like reduction at $17 \mathrm{~cm}$ depth. Values below this point are lower than those above, although a slight increase is visible below $27 \mathrm{~cm}$. LOI values from cores LEDV4 and LEDV5 are highly correlated $(r>0.9)$

The profile of sulphur $(\mathrm{S})$ is rather different from the profiles discussed above. Although $\mathrm{S}$ concentrations in the top part of the core do exceed those in the lower 


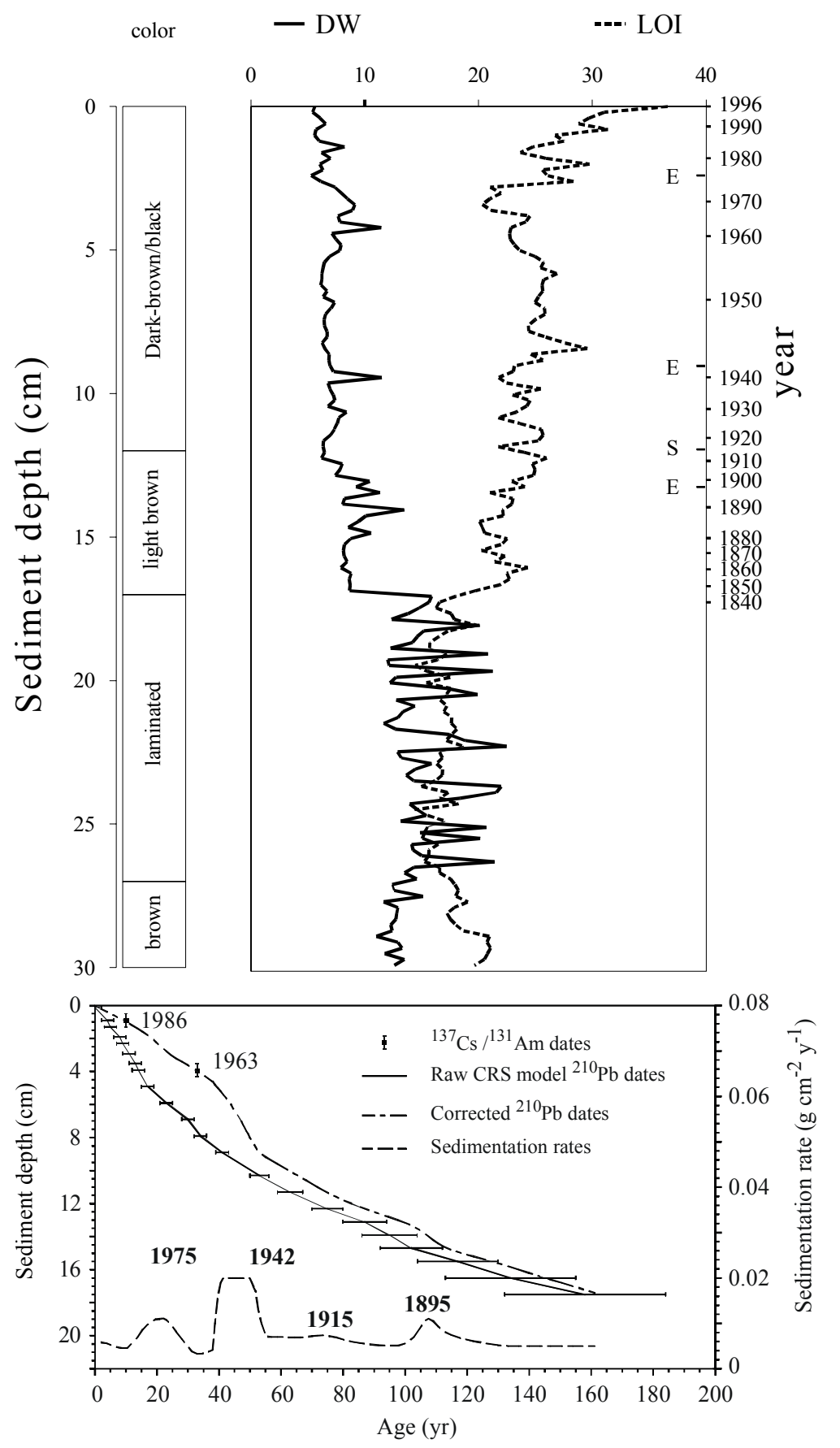

Fig. 3. Dry weight (DW; \% wet weight) and loss-on-ignition (LOI; \% dry weight) profiles in sediment from Jezero v Ledvici (NW Slovenia). $\mathrm{E}=$ earthquake; $\mathrm{S}=$ slope collapse.

Fig. 4. Radiometric chronology of Jezero $\mathrm{v}$ Ledvici (NW Slovenia) core LEDV5 showing CRS model ${ }^{210} \mathrm{~Pb}$ dates together with dates determined from the ${ }^{137} \mathrm{Cs}$ and ${ }^{241} \mathrm{Am}$ stratigraphy. Also shown are the corrected ${ }^{210} \mathrm{~Pb}$ dates and sedimentation rates calculated using the ${ }^{137} \mathrm{Cs}$ and ${ }^{241} \mathrm{Am}$ dates as reference values (numbers indicate earthquakes and slope collapse)

part, this is limited to the first $12 \mathrm{~cm}$ instead of $17 \mathrm{~cm}$. Concentrations of $\mathrm{S}$ in the core section from $0-12 \mathrm{~cm}$ are also more variable, and three different phases can be recognised. In two phases $(0-4$ and $8-12 \mathrm{~cm})$ the values are high but in the intermediate phase $(4-8 \mathrm{~cm})$ they are clearly low.

\subsection{Pigments}

Chlorophyll derivatives (CD) and total carotenoid concentrations (TC) have similar down-core profiles with patterns very similar to that of sulphur. CD and TC are high from $0-4 \mathrm{~cm}$ and from $8-12 \mathrm{~cm}$, but low from $4-8 \mathrm{~cm}$ (Fig. 5). Below $12 \mathrm{~cm}$ there is a sharp decrease both in $\mathrm{CD}$ and $\mathrm{TC}$, and the values remain low and stable down to the bottom of the core. However, in the 12$17 \mathrm{~cm}$ and $26-30 \mathrm{~cm}$ sections of the core, $\mathrm{CD}$ and TC values are relatively high compared to the $17-26 \mathrm{~cm}$ section.

\subsection{Diatoms}

The same samples used for the pigment analyses were used in the subsequent analyses of diatoms and 

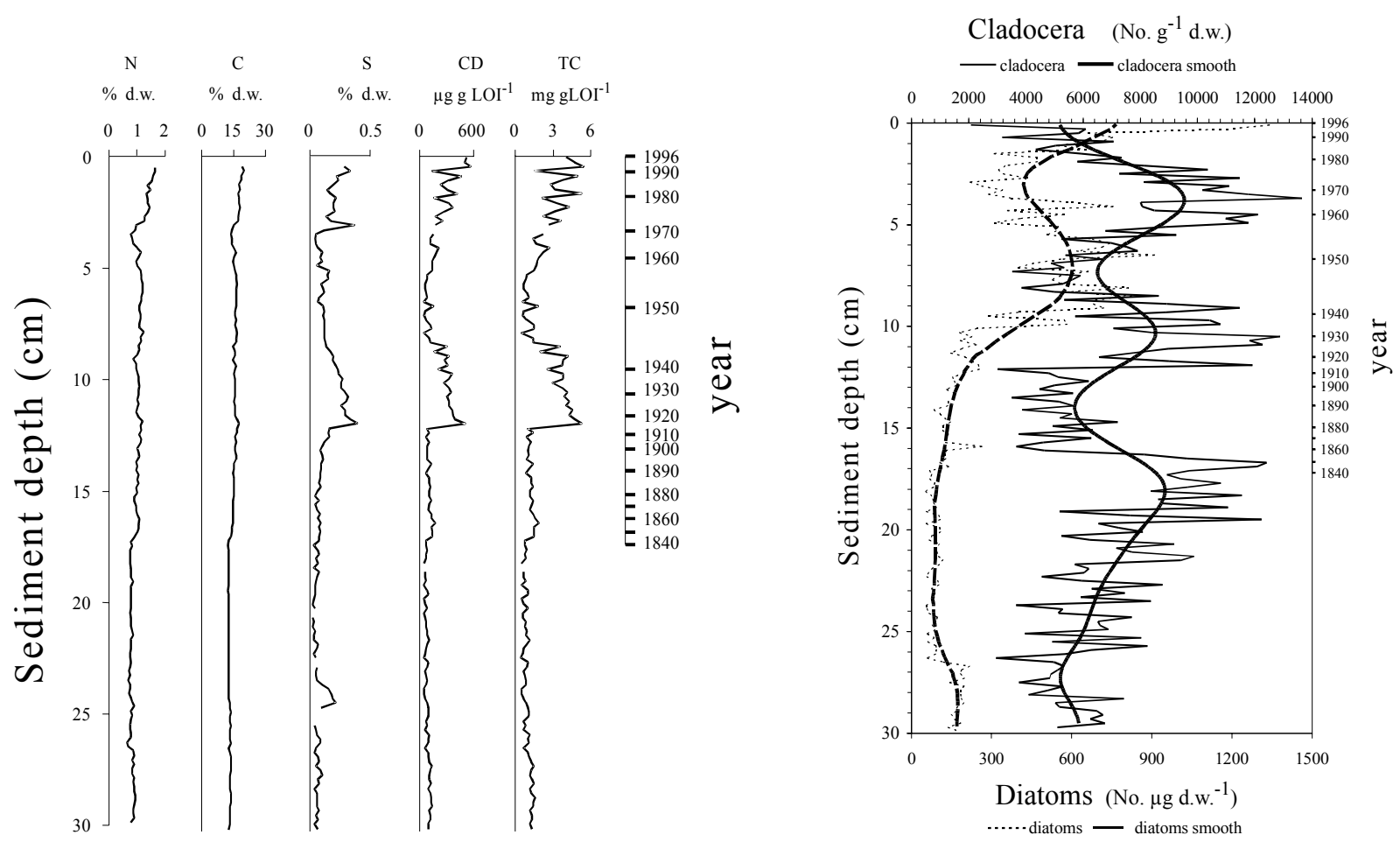

Fig. 5. Carbon (C), nitrogen (N), sulphur (S), chlorophyll Fig. 6. Total number of diatom valves $\mu g-1$ DW and total number derivative (CD) and total carotenoid (TC) profiles in sediment of cladoceran remains g-1 DW in a sediment profile from Jezero from Jezero v Ledvici (NW Slovenia). v Ledvici (NW Slovenia).

cladoceran remains. Diatoms, expressed as the number of valves per $\mu \mathrm{g} \mathrm{DW}$ of sediment, are clearly more frequent in the upper part of the core (Fig. 6). Between the surface and a depth of $11-12 \mathrm{~cm}$ the number of valves is high, but oscillates between 200 and 1200 valves $\mu \mathrm{g}^{-1}$ DW. Below $12 \mathrm{~cm}$ the average concentration drops to $100-200$ valves $\mu \mathrm{g}^{-1} \mathrm{DW}$, with some increase in the section between 27 and $30 \mathrm{~cm}$. The most common of the 13 diatom species found are non-planktonic, with Denticula tenuis and Navicula cryptotenella occurring most frequently (Fig. 7). These taxa are most common in the upper $10 \mathrm{~cm}$ of sediment. An additional 6 species have a similar distribution, while 5 species are either distributed uniformly with depth or exhibit a slight increase towards the bottom of the core.

Diatom accumulation rates (expressed as no. of valves $\mathrm{cm}^{-2} \mathrm{y}^{-1}$ ) show a slightly different pattern (Fig. 8 ). There is a minimal increase in the accumulation rates from $1835(17.4 \mathrm{~cm}$ depth) to about $1940(9.2 \mathrm{~cm}$ depth), followed by a sharp increase in the period from 1942 to 1960 (9.2-4.4 cm depth). From 1975 (2.4 cm depth) onwards there is an increase in accumulation rate. Six out of seven of the most common diatom species show increased accumulation rates between $10 \mathrm{~cm}$ and $9 \mathrm{~cm}$ and a minimum around $3 \mathrm{~cm}$, followed by another increase towards the surface. According to the
${ }^{210} \mathrm{~Pb}$ time scale, both increases in diatoms begin after the occurrence of earthquakes in 1942 and 1976.

\subsection{Cladocera}

The number of cladoceran remains oscillates between 3000 and $13000 \mathrm{~g}^{-1} \mathrm{DW}$ throughout the core (Fig. 6). The most dramatic decrease is at a depth of $17 \mathrm{~cm}$ (about 1850). Numbers remain low between 17 and 12 $\mathrm{cm}$ (about 1915), after which they increase again to the same level. The highest accumulation rates of cladocerans (as number of remains $\mathrm{cm}^{-2} \mathrm{y}^{-1}$ ), and also of each particular taxon, occurred after 1942 and 1975 (Fig. 9).

Of the four cladoceran species found, only one was planktonic. This species was poorly represented, as was the benthic species Alona sp. Most of the remains found were of Chydorus sphaericus. These were most abundant below a depth of $16 \mathrm{~cm}$ (i.e., before about 1860). Above a depth of $12 \mathrm{~cm}$ (about 1915) its remains were only twice as frequent as those of Alona (=Biapertura) affinis. The frequency of $A$. affinis increases particularly strongly between 9.5 and $5.0 \mathrm{~cm}$ (representing the period between 1940 and 1955), and between 3.5 and 1.8 cm (1965 - 1980). A hump-backed form of C. sphaericus, a special ecophenotype and an indicator of lowtemperature environments (Brancelj 1996), was consistently present, but at low frequencies. 


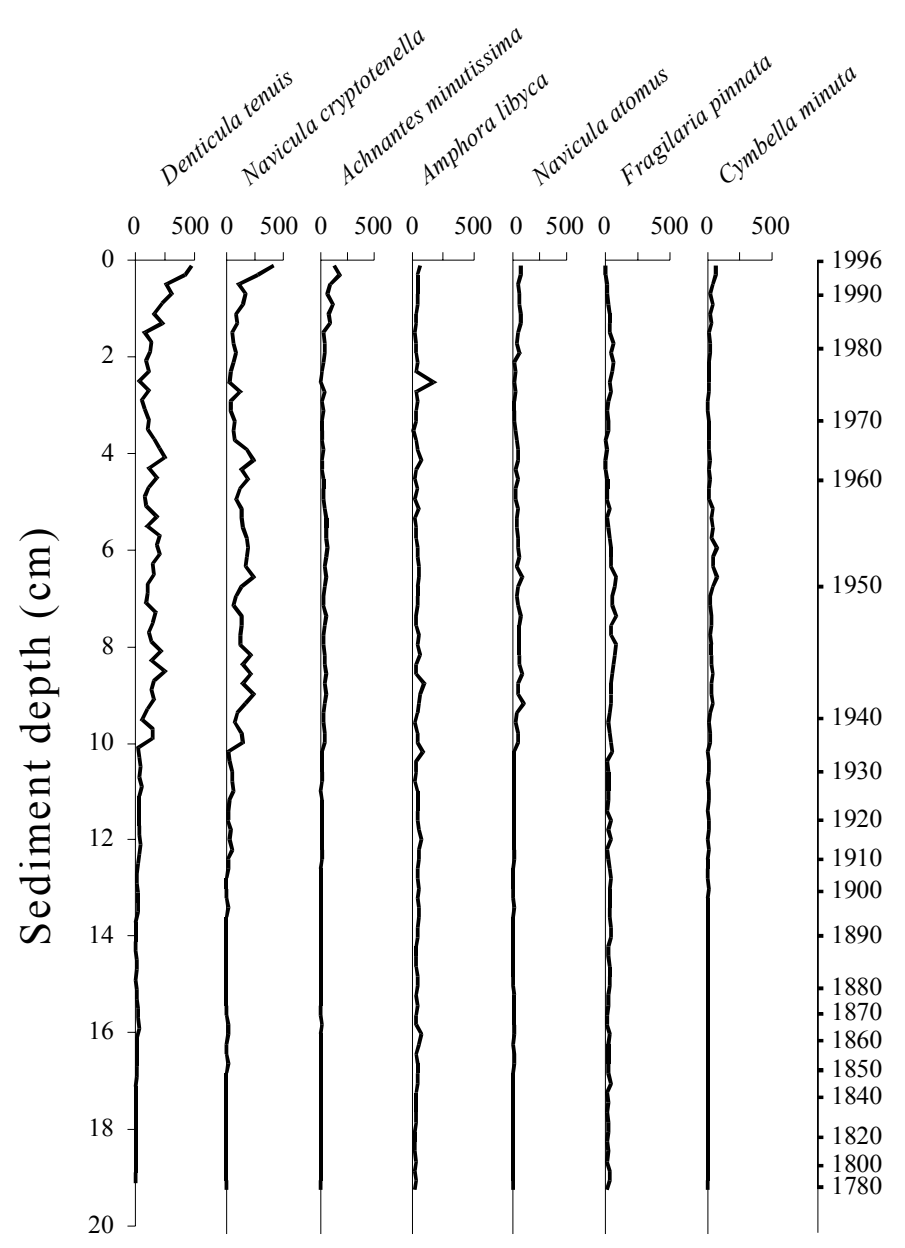

Fig. 7. Distribution of seven of the most common diatoms in a sediment profile from Jezero $\mathrm{v}$ Ledvici (NW Slovenia). Values as Number of valves $\mu \mathrm{g}^{-1} \mathrm{~d}$.w.

\subsection{Tree-ring width index and dendroclimatology}

The tree-ring width index, based on 12 samples of European Larch (Larix decidua) from the vicinity of the lake, covers a period of 136 y (1860-1996) (Fig. 10). As a result of harsh edaphic and climatic conditions, the radial increment is relatively low, about $0.9 \mathrm{~mm} \mathrm{y}^{-1}$. This indicates that trees were frequently exposed to stressful conditions, resulting in several years with a depression in tree growth. The most stressful conditions appeared between 1880-1890, 1908-1915, 1919-1921, 1952-1965, and around 1980. Periods of intensive positive tree-ring increments were short. These results agree with similar studies carried out in some other regions of the Julian Alps (Ogrin unpubl.)

\subsection{Relations between environmental factors and biota}

The relationship between the tree-ring width index and the reconstructed air temperature at Jezero v Ledvici (Agustí-Panareda et al. 2000; Agustí-Panareda \& Thompson 2000), expressed either as an annual mean or a summer mean (June-August), is positive but weak $(\mathrm{r}=0.11$ for the annual mean temperature). However, after introducing a lag of $4 \mathrm{y}$, the relationship becomes more pronounced $(r=0.24)$, indicating the long-term ef- fects of environmental factors. In the period for which reconstructed air temperatures are available (17811996), the accumulation rates of cladocerans and diatoms were strongly related to one another $(r=0.71$; Fig. 11 ), indicating that both groups of organisms generally reacted similarly to the environmental factors prevailing during the last $120 \mathrm{y}$. The exception is the last three decades, when eutrophication was the most important factor.

Previous to 1900 , diatom abundance shows no relationship to the reconstructed mean air temperature. After 1900, however, similar positive trends are observed in both variables (Fig. 8). The same trends are observed in several diatom species: N. cryptotenella, N. atomus, $D$. tenuis, A. minutissima and $C$. minuta. These taxa were rare before 1942 ( $9 \mathrm{~cm}$ depth), but very abundant from 1942-1955 (based on accumulation rates). In the period between 1955 and 1975 (5.5-2.4 cm depth) diatom accumulation rates were low, but increased again after 1975.

Diatom abundance is only very weakly correlated with the tree-ring width index (an indicator of terrestrial environmental conditions). Among the dominant seven diatom taxa, only Fragilaria pinnata and Amphora lybica had a negative relationship with the tree-ring width index, interrupted only in the period between 1942 and 


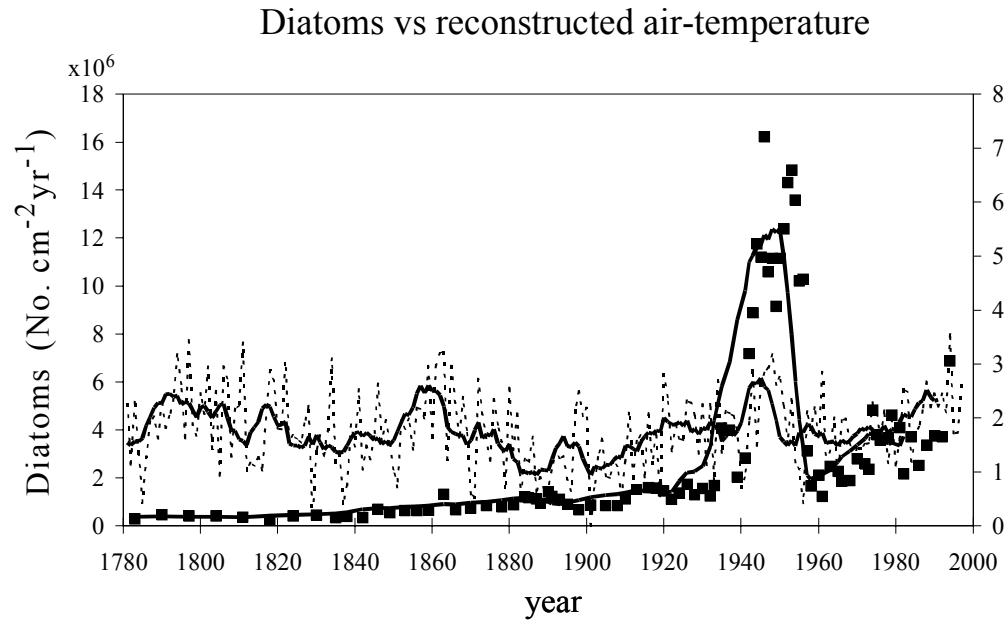

Cladocera vs reconstructed air-temperature
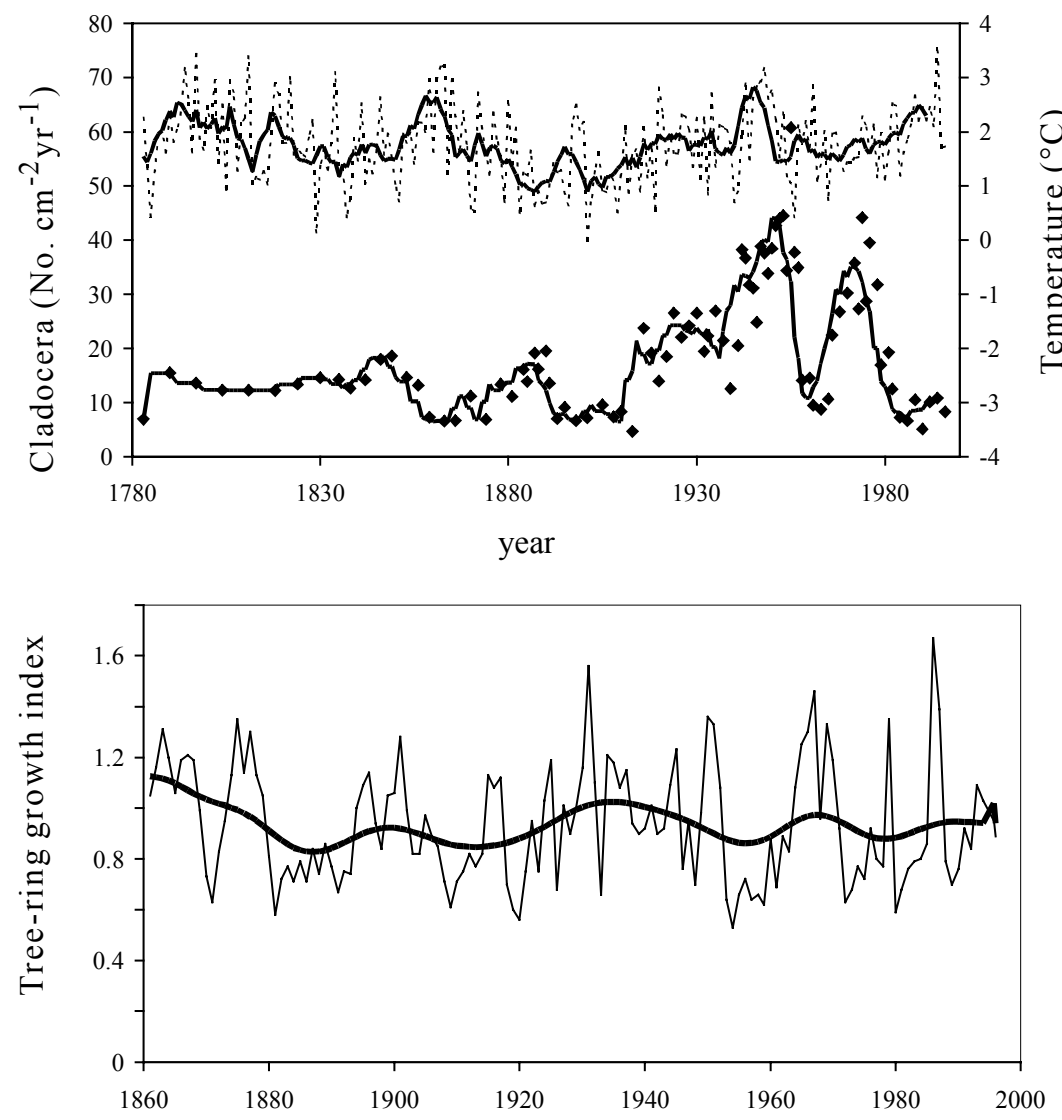

Fig. 8. Comparison of diatom accumulation rates (number of valves $\mathrm{cm}^{-2} \mathrm{y}^{-1}$ ) (black squares) with the reconstructed mean annual air temperature at Jezero v Ledvici (NW Slovenia). (Agustí-Panareda \& Thompson 2000) for the period 1781-1996. Trendlines (6-y moving average) for both values are added.
Fig. 10. The tree-ring width index for European Larch (Larix decidua) from the shore of Jezero v Ledvici (NW Slovenia).
1955 (Fig. 12). The rest of the diatom taxa show no correlation with the tree-ring width index.

Based on accumulation rates, the cladoceran community exhibits a slightly negative relationship to the reconstructed mean air temperature (Fig. 9) However, the relationship between cladocerans and environmental factors is more evident when cladoceran accumulation rates are compared with the tree-ring width index (Fig.
Fig. 9. Comparison of the accumulation rate of cladoceran remains (number of remains $\mathrm{cm}^{-2}$ $\mathrm{y}^{-1}$ ) (lower graph) with the reconstructed mean annual air temperature at Jezero v Ledvici (NW Slovenia). (Agustí-Panareda \& Thompson 2000) for the period 1781-1996. Trendlines (6-y moving average) for both values are added.
13), considered as a composite environmental indicator. A similar negative relationship can be observed between tree-ring width index and Chydorus and Biapertura (=Alona), whilst for Daphnia the relationship is less clear. The relationships between cladocerans and temperature, and between cladocerans and the tree-ring width index, are blurred between 1942 and 1980 as a result of the occurrence of earthquakes. 


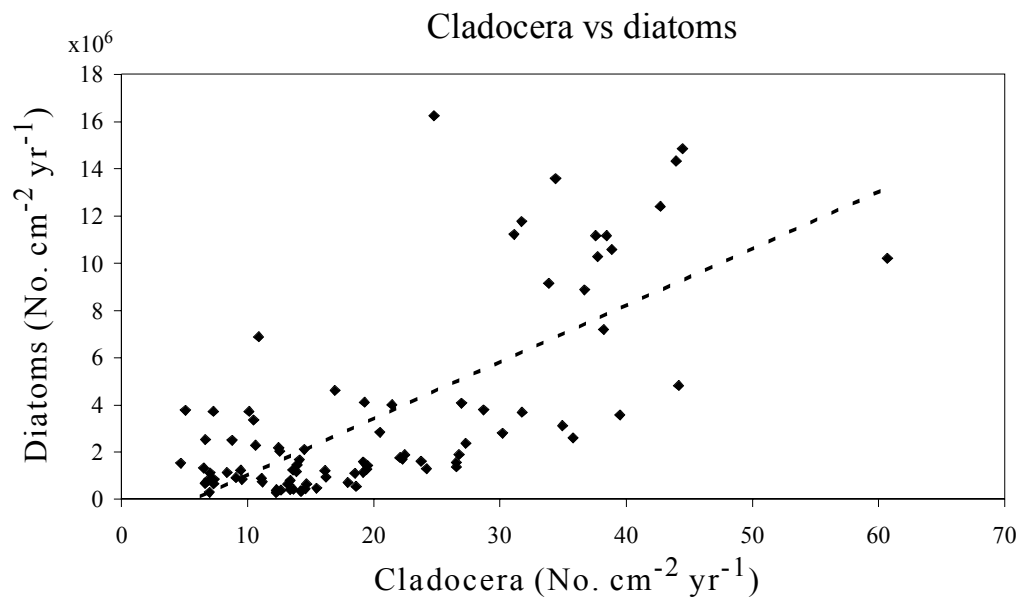

Fig. 11. Correlation between number of diatoms and number of cladoceran remains, calculated on the basis of saccumulation rates (number of remains $\mathrm{cm}^{-2} \mathrm{y}^{-1}$ ) for the period 1781-1996. Lake Jezero v Ledvici (NW Slovenia).

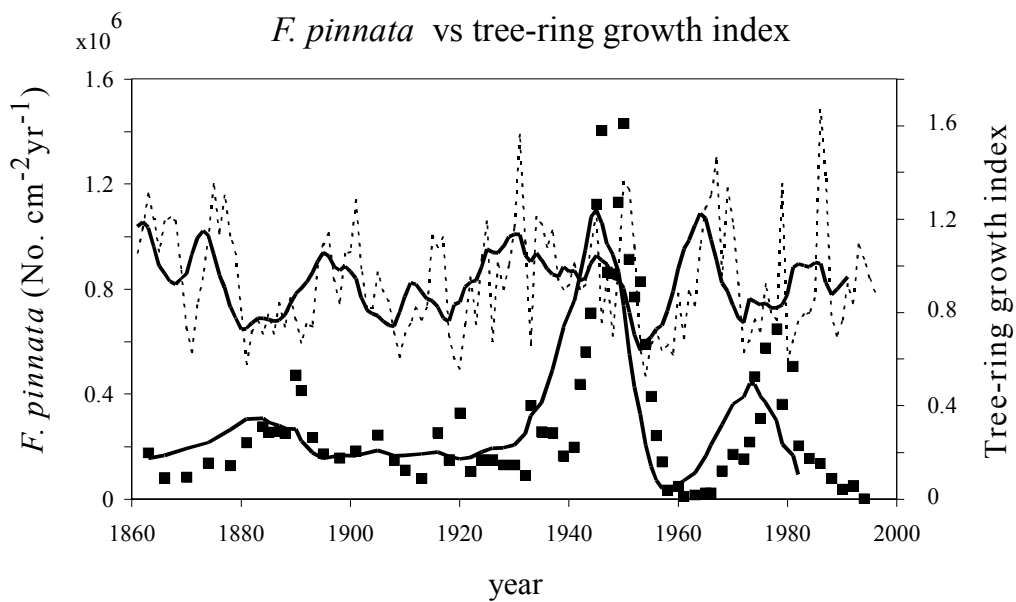

Fig. 12. Comparison of $F$. pinnata

accumulation rates (number of valves $\mathrm{cm}^{-2} \mathrm{y}^{-1}$ ) (black squares) with the tree-ring width index at Jezero v Ledvici (NW Slovenia) for the period 1861-1996. Trendlines (6-y moving average) for both values are added.

Cladocera vs tree-ring growth index

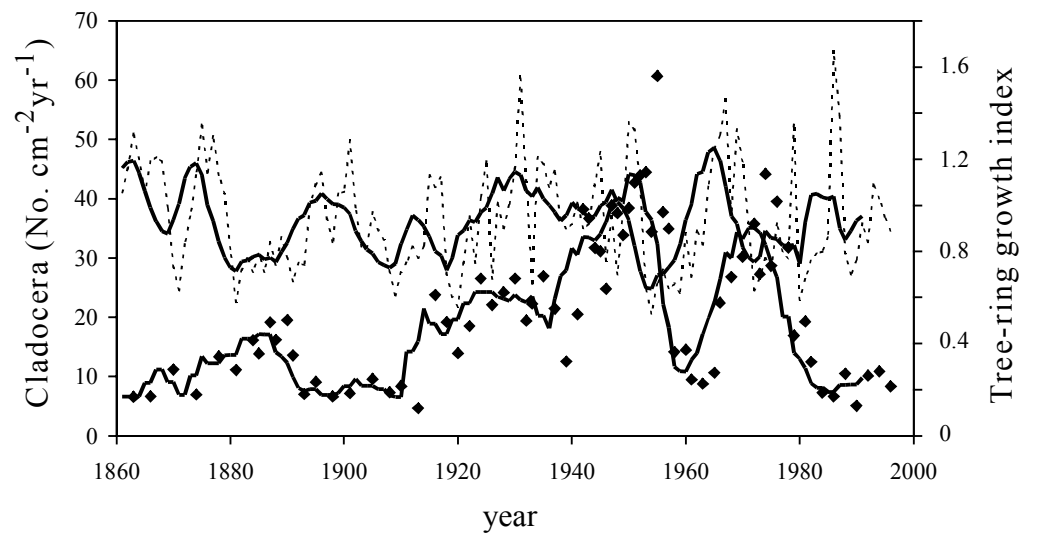

Fig. 13. Comparison of cladoceran accumulation (number of remains $\mathrm{cm}^{-2} \mathrm{y}^{-1}$ ) (black squares) with the tree-ring width index at Jezero v Ledvici (NW Slovenia) for the period 1861-1996. Trendlines (6-y moving average) for both values are added.

\section{DISCUSSION}

\subsection{Ice cover}

During the winters of both 1996-97 and 1997-98, Jezero v Ledvici experienced more than 6 months of ice cover, i.e. from approximately the middle of November till the end of May (Fig. 2i). Although local topographic effects on incident solar radiation at the lake are not negligible and thus could have a considerable effect on the lake ice cover (cf. Livingstone et al. 1999), the onset and end of the period of ice cover are still likely to be governed to a large extent by synoptic-scale climate integrated over several weeks, particularly by air temperature (e.g. Palecki \& Barry 1986; Ruosteenoja 1986; Livingstone 1997). The timing of freeze-up is thus likely to reflect the air temperatures prevailing at the lake during October/November, and in fact a comparison of figures $2 \mathrm{a}$ and $2 \mathrm{i}$ reveals that in both November 1996 and November 1997, freeze-up occurred shortly after the first occurrence of negative daily mean air temperatures. By the same token, the timing of break-up 
is likely to reflect the air temperatures prevailing during April/May. Again, it can be seen from figures $2 \mathrm{a}$ and $2 \mathrm{i}$ that break-up in May 1997 occurred within a few weeks of positive daily mean air temperatures having been attained. Break-up in May 1998 occurred earlier than in 1997: on 29 May 1997, 50\% of the lake was still icecovered, whereas on 21 May 1998, only a few ice floes were visible. This is presumably associated with the earlier occurrence of positive daily mean air temperatures in 1998 in comparison with 1997. In common with other high-altitude lakes, because of the long period of ice cover, the influence of climatic forcing on the ecology of Jezero $v$ Ledvici may be largely indirect (via the timing of the onset and end of the ice cover) and accompanied by a time lag.

\subsection{Core analyses}

The cores taken from Jezero $\mathrm{v}$ Ledvici can be divided into two sections. The upper part of the core (above $17.4 \mathrm{~cm}$ ) was dated and compared with the air temperature reconstruction of Agustí-Panareda et al. (2000) and Agustí-Panareda \& Thompson (2000), and also with the tree-ring width index. Sediment at a depth of $17.4 \mathrm{~cm}$ is $161 \pm 25 \mathrm{y}$ old, and by linear extrapolation we can estimate that sediment at a depth of $30 \mathrm{~cm}$ is about $600 \mathrm{y}$ old. The structure of the sediment (in terms of DW or LOI) shows several periods in the onthogeny of the lake in the last $600 \mathrm{y}$, with the most drastic change having occurred at a depth of about $17 \mathrm{~cm}$. Below $17 \mathrm{~cm}$ there is a relatively stable period with low diatom abundance, whilst cladoceran remains are much more abundant, with $C$. sphaericus dominating. The upper part of the sediment, encompassing the time span since about 160 y BP, was interrupted at least three times, resulting in increased sedimentation rates (Fig. 4). These interruptions coincide well with three earthquakes known to have occurred in the area during the last $100 \mathrm{y}$ - in 1895 (at about $13 \mathrm{~cm}$ depth), 1942 (at about $9 \mathrm{~cm}$ ) and 1975/76 (at about $2.8 \mathrm{~cm}$ ). In the periods following these events, increased accumulation rates of diatoms and cladocerans can be observed, and quantitative changes in both groups also occur. We presume that the effect of the earthquakes was to trigger slope collapse (snow and/or stone) on the land, which then affected sediment resuspension. It is rather improbable that the earthquakes were the direct cause of resuspension via sediment slumping within the lake itself.

The frequency of periods of extreme stress, reflected in double or missing tree-ring increments in the European Larch, enable us to reconstruct an exact tree-ring width index related to climatic factors. It seems that severe events, e.g., frosts, wind, or damage caused by the weight of snow, are more important for tree growth in this location than under average climatic conditions, and that these could effect tree growth for several years (Hughes et al. 1982). At Jezero v Ledvici the lag period is up to four years. Nevertheless, the tree-ring width in- dex from the lake shows only slight long-term oscillations around the mean value and only a minimal increasing trend over the last 100 y (Fig. 10). During the same period, the mean annual reconstructed temperature of Agustí-Panareda \& Thompson (2000) increased by about $1.5{ }^{\circ} \mathrm{C}$ (Fig. 8). The history of the lake during the last 100 y can be divided into three relatively well-defined periods: 1895-1942, 1942-1960 and from 1960 to the present. The first two periods were characterized by earthquakes and the third by climate change (an increased mean annual temperature). The third strong earthquake occurred in 1976, but the effects of this were less evident than in the previous two cases, possibly because its influence was masked by that of increasing temperatures.

\subsection{Response of diatoms and benthic cladocerans to environmental change after 1781}

Two environmental factors controlling diatom populations in the lake could be discerned. Eutrophication induced by earthquakes prevailed before 1960. Until 1940 the number of diatom valves per gram DW in the lake was low, but with a slight overall increasing trend (Fig. 6). In particular, an increase after the 1895 earthquake and decreases (possibly due to dilution as a result of slope collapse) around 1915 and 1930 are obvious. Previous to 1940 , no strong relationship with temperature or tree-ring width index could be recognised (Figs 8, 12). An event around 1915 (slope collapse?) dramatically increased the concentration of pigments and sulphur, but resulted in only a slight increase in the diatom accumulation rate.

The most obvious change in the diatom accumulation rate occurred immediately after the 1942 earthquake, when it increased dramatically, although the net effect of the earthquake recorded in the sediment was a dilution of diatom and cladoceran remains that lasted until 1960. The period from 1940 to 1954 was characterized by increasing mean air temperatures, but this appears to have had no direct impact on the diatom community. For example, $F$. pinnata appears to be negatively correlated with the mean air temperature and the tree-ring width index, but its population increase after the earthquake is similar to that of the rest of the diatom community. Between 1780 and 1960, diatom accumulation rates showed a tendency to return to low values after each earthquake. A homeostasis of the lake in that period appears to have minimised the effects of the earthquakes. After 1960, diatom abundance starts to increase, following the increase in air temperature (Fig. 8). Only in the case of Fragilaria and Amphora did the accumulation rate decrease during this period.

The accumulation rates of cladocerans (number $\mathrm{cm}^{-2}$ $\mathrm{y}^{-1}$ ) (Figs. 9, 13), as well as those of taxa of Chydorus, Biapertura and Daphnia, followed a similar pattern to that of the diatom accumulation rates (Fig. 8), increasing after each earthquake, and resulting in a positive 
correlation between cladocerans and diatoms (Fig. 11). The main difference between diatoms and cladocerans appears after 1975 onward, when the cladoceran community decreased (Fig. 13), similar to F. pinnata (Fig. 12). whilst the rest of the diatom community increased (Fig. 8). It seems increased mean annual temperature has that had a negative effect on benthic cladocerans in the last three decades and the opposite effect on diatoms, increasing their abundance.

According to Pražákova \& Fott (1994), the extent of the littoral zone of the lake is the main factor positively related to the abundance of remains of chydorid cladocerans. In Jezero v Ledvici this is not the case, because the core surface sediment sample shows high diatom abundance and low abundance of Chydorus and Biapertura. The high transparency of the water extends the littoral zone over the entire lake, i.e. towards the deepest point of the lake. The populations of Chydorus and Biapertura could not keep the population of diatoms at a low level. It is likely that today's diatom community is controlled by the level of nutrients rather than by grazing.

Chydorus sphaericus is among the most common cladoceran species, living in many freshwater habitats (Freyer 1993; Margaritora 1985). In the pelagic zone of lowland lakes, the population of $C$. sphaericus usually increases when eutrophication takes place (Vijverberg \& Boersma 1997). In Jezero v Ledvici in recent decades there has been a slight eutrophication as a result of the effects of earthquakes combined with an increase in mean annual air temperature; this has resulted in a relative increase in the number of Biapertura remains in the sediment. During scuba diving in September 1995 we found that Chydorus was limited to the upper littoral zone (mainly between 2.5 and $7.5 \mathrm{~m}$ ), whilst Biapertura prevailed below a depth of $7.5 \mathrm{~m}$. The shift from Chydorus dominance toward co-existence with Biapertura could be related to increased bioproduction in the lake from about 1915 onward. Biapertura is reported to be more common in the littoral zone of oligotrophic systems, particularly those covered with dense vegetation (Alonso 1996; Freyer 1993; Margaritora 1985). In Jezero $v$ Ledvici there are no macrophytes, but the population of epilithic diatoms is quite dense. Therefore epilithic diatoms could to some degree replace macrophytes and explain the relative increase of Biapertura in recent decades, particularly since the mid-1950s. Biapertura is frequently found in water bodies with a relatively high temperature. Nevertheless, the overall number of benthic cladocerans is decreasing.

\section{ACKNOWLEDGMENTS}

We would like to thank all our colleagues from the National Institute of Biology and University College London who helped with field work in Slovenia, to L. Corbella who helped with the elemental analysis, and to A. Agustí-Panareda and R. Thompson for their air tem- perature reconstruction. Funding was provided by the European Union within the framework of the EU Environment and Climate project MOLAR ('Measuring and Modelling the Dynamic Response of Remote Mountain Lake Ecosystems to Environmental Change: a Programme of Mountain Lake Research'; Contract Nos. ENV4-CT95-007 and ERB IC20 CT9), by the Slovenian Ministry of Science and Technology ('SLO-Alpe'; Contract No. J1-7414-0105), and by the Swiss Federal Office of Education and Science (Contract No. 95.0518$1)$.

\section{REFERENCES}

Agustí-Panareda, A., R. Thompson \& D.M. Livingstone. 2000. Reconstructing temperature variations at high elevation lake sites in Europe during the instrumental period. Verh. int. Ver. Limnol., 27: (in press).

Agustí-Panareda, A. \& R. Thompson. 2000. Retrodiction of air temperature at eleven remote alpine and arctic lakes in Europe from 1781 to 1997 AD. J. Paleolimnol.: (in press).

Alonso, M. 1996. Crustacea: Branchiopoda. Fauna Iberica, vol. 7. Museo Nacional de Ciencias Naturales; Madrid: $486 \mathrm{pp}$.

Appleby, P.G. 1993. Forward to the ${ }^{210} \mathrm{~Pb}$ dating anniversary series. J. Paleolimnol., 9: 155-160.

Appleby, P.G. 1998. Dating recent sediments by ${ }^{210} \mathrm{~Pb}$ : Problems and solutions. Proc. 2nd NKS/EKO-1 Seminar, Helsinki, 2-4 April 1997.

Appleby, P.G., P.J. Nolan, D.W. Gifford, M.J. Godfrey, F. Oldfield, N.J. Anderson \& R.W. Battarbee. $1986 .{ }^{210} \mathrm{~Pb}$ dating by low background gamma counting. Hydrobiologia, 141: 21-27.

Appleby, P.G., N. Richardson \& P.J. Nolan. 1992. Self-absorption corrections for well-type germanium detectors. Nucl. Inst. \& Methods B, 71: 228-233.

Battarbee, R.W. 1986. Diatom analysis. In: B.E. Berglund (Ed.), Handbook of Holocene palaeoecology \& palaeohydrology. J. Wiley, Chichester: 527-570.

Battarbee, R.W.1995. Using sediment records to infer the medium and long-term variability of alpine lake ecosystems. In: K. Hanselmann, H. Lang \& U. Moser (Eds), The Role of the Hydrological Cycle in Mountain Ecosystems. 16-17 Nov. 1995. University of Zurich-Irchel.

Bennion, H. 1994. A diatom-phosphorus transfer function for shallow, eutrophic ponds in southeast England. Hydrobiologia, 275/276: 391-410.

Berglund, B.E. 1986. Handbook of Holocene palaeoecology and palaeohydrology. Wiley, Chichester: $869 \mathrm{pp}$.

Bernot, F. 1998. Padavine (Precipitation). In: Gams I. \& I. Vrišer (Eds), Geografija Slovenije. Slovenska matica v Ljubljani: 120-138.

Bradbury, J.P. W.E. Dean. 1993. Elk Lake, Minnesota: evidence for rapid climate changes in the North-Central United States. Special paper 276. U.S. Geological Survey MS-919 (JPB), MS-939 (WED), Denver, Colorado: 336 pp.

Brancelj, A. 1996. Chydorus 'mutilus' Kreis, 1921 - a postephippial form of Chydorus sphaericus (O.F. Müller 1785). Hydrobiologia, 323: 45-59.

Brancelj, A., M. Šiško, G. Kosi. 1997. Distribution of algae and crustacea (Copepoda \& Cladocera) in mountain lakes in Slovenia with different trophic levels. Period. Biol., 99(1): 87-96.

Brancelj, A., M. Šiško, G. Muri, C. Kamenik, P. Appleby, A. Lami, E. Shilland, N.L. Rose, J.S. Brooks \& J.A. Dearing. (2000). Lake Jezero v Ledvici (NW Slovenia) - impacts of earthquakes and climate change on the lake ecosystem. $J$. Paleolimnol.: (submitted). 
Brock, T.D. 1981. Calculating solar radiation for ecological studies. Ecol. Model., 14: 1-19.

Bührer, H. \& H. Ambühl. 1975. Die Einleitung von gereinigtem Abwasser in Seen. Schweiz. J. Hydrol., 37: 347369.

Camarero, L., J. Catalan, A. Boggero, A. Marchetto, R. Mosello \& R. Psenner. 1995. Acidification in high mountain lakes in Central, Southwest, and Southeast Europe (Alps, Pyrenees, Pirin). Limnologica, 25(2): 141-156.

Cook, E.R. \& L.A. Kairiukstis. 1990. Methods of Dendrochronology. Kluwer Academic Publisher, Dordrecht: 391 pp.

Dean, W.E. Jr. 1974. Determination of carbonate and organic matter in calcareous sediments and sedimentary rocks by loss on ignition: comparison with other methods. J. Sedim. Petrology, 44: 242-248.

Freyer, G. 1993. The freshwater crustacea of Yorkshire: a faunistical \& ecological survey. Yorkshire Naturalist's Union \& Leeds Philosophical and Literature Society: 312 pp.

Fritts, H. C. 1976. Tree Rings and Climate. Academic Press, London: $567 \mathrm{pp}$.

Fritz, S.C. 1989. Lake development and limnological response to prehistoric and historic landuse in Diss, Norfolk, U.K. J. Ecol., 77: 182-202.

Hofmann, W. 1987. Cladocera in space and time: Analysis of lake sediments. Hydrobiologia, 145: 315-321.

Hottel, H. C. 1976. A simple model for estimating the transmittance of direct solar radiation through clear atmosphere. Solar Energy, 18: 129-134.

Hughes, M.K., P.M. Kelly, J.R. Pilcher \& V.C. La Marche. 1982. Climate from Tree Rings. Camridge Univ. Press, Cambridge: $210 \mathrm{pp}$.

Jacoby, G.C., P.L. Williams \& B.M. Buckley. 1992. Tree ring correlation between prehistoric landslides and abrupt tectonic events in Seattle, Washington. Science, 258(5088) 1621-1623.

Joshi, S.R., B.S. Shukla \& R. McNeely. 1988. The calculation of lead-210 dates for McKay lake sediments. J. Radioanal. Nucl. Chem., Articles, 125(2): 341-349.

Karlin, R.E. \& S.E.B. Abella. 1992. Paleoearthquakes in the Puget Sound region recorded in sediments from Lake Washington, USA. Science, 258(5088):1617-1620.

Krammer, K. \& H. Lange-Bertalot. 1991. Bacillariophyceae. 4.Teil: Achnanthaceae, Kritische Ergänzungen zu Navicula (Lineolatae) und Gomphonema Gesamtliteraturverzeichnis Teil 1-4. In: A. Pascher (Ed.), Süßwasserflora von Mitteleuropa. Gustav Fischer Verlag, Stuttgart: 437 pp.

Lami, A., F. Niessen, P. Guilizzoni, J. Massaferro \& C.A. Belis. 1994. Palaeolimnological studies of the eutrophication of volcanic Lake Albano (Central Italy). J. Paleolimnol., 10: 181-197.

Livingstone, D.M. 1997. Break-up dates of Alpine lakes as proxy data for local and regional mean surface mean surface air temperatures. Clim. Change, 37: 407-439.

Livingstone, D.M. \& A.F. Lotter. 1998. The relationship between air and water temperatures in lakes of the Swiss Plateau: a case study with palaeolimnological implications. J. Paleolimnol., 19: 181-198.

Livingstone, D.M., A.F. Lotter \& I.R. Walker. 1999. The decrease in summer surface water temperature with altitude in Swiss Alpine lakes: a comparison with air temperature lapse rates. Arctic Antarctic Alpine Res., 31(4), 341-352.

Manca, M., A.M. Nocentini, C.A. Belis, P. Comoli \& L. Corbella. 1994. Variations of fossil Cladocera in the sediments of Lake Orta (N Italy) over the last 400 years. $J$. Paleolimnol., 14: 113-122.

Margaritora, F.G. 1985. Cladocera. Fauna d'Italia. Calderini, Bologna: 399 pp.
Melik, A. 1950. Planine v Julijskih Alpah (L'economie pastorale dans les Alpes Juliennes). Dela Inštituta za geografijo, SAZU, Ljubljana: $301 \mathrm{pp}$.

Mirecki, J.E. 1996. Recognition of the 1811-1812 New Madrid Earthquakes in Reelfoot Lake, Tennessee sediments using pollen data. J. Paleolimnol.,15: 183-191.

Mosello, R., B.M. Wathne, L. Lien \& H.J.B. Birks. 1995a. AL:PE projects: Water chemistry and critical loads. Wat. Air Soil Poll., 85(2): 493-498.

Mosello, R., A. Marchetto, A. Barbieri \& A. Bernasconi. $1995 \mathrm{~b}$. Seasonal variations and trends of atmosphereborne nutrient load to the alpine biosphere and pedosphere. In: K. Hanselmann, H. Lang \& U. Moser (Eds), The Role of the Hydrological Cycle in Mountain Ecosystems. 16-17 Nov. 1995. University of Zurich-Irchel.

Oldfield, F. \& P.G. Appleby. 1984. Empirical testing of ${ }^{210} \mathrm{~Pb}$ dating models for lake sediments. In: Haworth, E.Y. \& J.G.Lund (Eds), Lake Sediments and Environmental History. Leicester University Press.

Oviatt, C.G., G.D. Habiger \& J.E. Hay. 1994. Variation in the composition of Lake Bonneville marl: A potential key to lake-level fluctuations and paleoclimate. J. Paleolimnol., 11(1): 19-30.

Palecki, M.A. \& R.G. Barry. 1986. Freeze-up and break-up of lakes as an index of temperature changes during the transition seasons: a case study for Finland. J. Clim. Appl. Meteor., 25: 893-902.

Pražákova, M. \& J. Fott. 1994. Zooplankton decline in the Černé Lake (Šumava Mountains, Bohemia) as reflected in the stratification of cladocera remains in the sediment. Hydrobiologia, 274: 121-126.

Psenner, R. 1995. Airborne dust: a major influence on the chemistry and biology of alpine lakes. In: K. Hanselmann, H. Lang \& U. Moser (Eds), The Role of the Hydrological Cycle in Mountain Ecosystems. 16-17 Nov. 1995. University of Zurich-Irchel.

Ribarič, V. 1982. Seizmičnost Slovenije. Katalog potresov (792 n.št.-1981), Seizmološki zavod SR Slovenije, Ljubljana: 649 pp.

Ribičič, M., Vidrih, R., 1999. Earthquake on 12 April, 1998 in Posočje - Damage to nature. In: International Conference on Earthquake Hazard and Risk in the Mediterranean Region, 18.-22. October 1999, Nikosia, North Cyprus, EHRMR 99 Abstracts, 227.

Rolland, C. 1993. Tree-rings and climate relationship for Abies alba in the Internal Alps. Tree-Rings Bull., 53:1-11.

Ruosteenoja, K., 1986. The date of break-up of lake ice as a climatic index. Geophysica, 22: 89-99.

Sanger, J.E. 1988: Fossil pigments in palaeoecology and palaeolimnology. Palaeogeography, Palaeoclimatology, Palaeoecology, 62: 343-359.

Smol, J.P. 1990. Paleolimnology: recent advances and future challenges. Mem. Ist. ital. Idrobiol., 47: 253-276.

Swain, E.B. 1985. Measurements and interpretation of sedimentary pigments. Freshwat. Biol., 15: 53-75.

Vidrih, R., I. Cecič \& P. Sinčič. 1995. The Ljubljana, Slovenia earthquake on April 14 ${ }^{\text {th }}, 1895$. Geophysical Survey of Slovenia, Ljubljana: 9 pp.

Vijverberg, J. \& M. Boersma. 1997. Long-term dynamics of small-bodied and large-bodied cladocerans during the eutrophication of a shallow reservoir, with special attention for Chydorus sphaericus. Hydrobiologia, 360: 233242.

Wetzel, R.G., 1970. Recent and postglacial production rates of a marl lake. Limnol. Oceanogr., 15: 491-503.

Züllig, H. 1982. Untersuchungen über die Stratigraphie von Carotinoiden im geschichteten Sediment von 10 Schweizer Seen zur Erkundung früherer PhytoplanktonEntfaltungen. Schweiz. Z. Hydrol., 44: 1-98. 